\title{
Analysis of Fintech Revolution in China and the UK: A Comparison of Ant Check Later and Zopa
}

\author{
Kemo Badiane \\ Luo Yu \\ Wong Mun Wui \\ Nanfang College of Sun Yat-Sen University, 882 \\ Wenquan Avenue, Guangzhou \\ China
}

\begin{abstract}
This study examines peer-to-peer lending in two platforms, Ant Check Later in China and Zopa in the United Kingdom. The objective is to analyze the two models of online credit to better understand their current status, analyze their development prospects and help individuals especially young people put into practice their entrepreneurial spirit. The methodologies used are literature analysis, qualitative comparison, and case analysis. It is by reading the relevant literature that a general impression of online credit is formed. By comparing online credit with traditional bank credit, we study the advantages of online credit and its barriers to development. The SWOT analysis of the two biggest companies in the online credit market helps us understand the differences between $B 2 C$ and $P 2 P$ models, realize the difference between domestic and international online credit markets, and recognize the online credit market development space, so that we can make online credit market predictions.
\end{abstract}

Keywords: Online credit, peer-to-peer lending, SWOT analysis, digital economy, China, United Kingdom

\section{Introduction}

With the development of China's economy, the material desire and the desire for a better life among people are getting stronger. This is an excellent opportunity for the development of online social lending (Meilleurtaux, 2015), which has become a trendy attractive option (Gonzalez \& McAleer, 2011). Online credit could effectively stimulate domestic demand and promote economic growth (Frenchweb, 2019). Online credit products are mainly divided into two models: business-to-consumer (B2C) and peer-to-peer (P2P). At present, the $\mathrm{B} 2 \mathrm{C}$ model is more popular than $\mathrm{P} 2 \mathrm{P}$, which are mainly small and medium enterprises (Yu, 2017). Most companies take an "e-commerce + finance" model, forming an industrial chain with consumers (and consumption scenes). Even though they are in the same industry, online credit and traditional bank credit are very different (Torres \& Xu, 2019). Each has its characteristics, so the two do not constitute too intense competition. Moreover, the comparison between "Ant Check Later" and "Zopa" allows us to understand that the B2C model of Chinese online credit is very advantageous: the favorable policies of the government, the considerable volume of customers, the evolution of the concept of mass consumption, the diversification of the consumer environment and the development of Internet technologies constitute an excellent environment for the development of online credit (Yu, 2017; Schiller, 1999).

The objective is to analyze the two models of online credit to better understand their current status, evaluate their development prospects and help people, especially young people, put their entrepreneurial desire into practice.

Thus, this study is structured as follows. Section 2 analyzes the general online credit situation in China. Section 3 compares the two credit models (Ant Check Later and Zopa). Section 4 discusses the development trends of online credit through this paper. Finally, section 5 presents our conclusion with discussions and directions for future research.

\section{The General Situation of Online Credit in China}

Just over the last decade, online credit emerged in the Chinese market (Chen \& Han, 2012). Its speed of development has far exceeded the imagination of people. By now, online credit has covered online retail services, and it is gradually expanding offline. This section will introduce the current state of online credit in China, how its industry chain operates, and compare it with traditional bank credit. 


\subsection{Presentation of online credit}

Online credit is an innovative form of credit that first appeared in the UK by a company called Zopa (Gonzalez \& McAleer, 2011). Its approval, accounting, clearing and regulatory processes are fully completed through the Internet (Patsuris, 1998). Lenders and borrowers can do the whole transaction from home (Lin et al., 2009; Collier, \& Hampshire, 2010; Bachmann et al., 2011). Generally, the online loan amount would not be too high; so, there is no need for any property mortgage. Online credit is generally divided into business-to-business (B2C) model and Consumer-to-consumer, e.g., C2C (P2P) model as exhibited in Figure 1. In China, the development of online credit is still in its infancy stage, but it has grown quite rapidly.

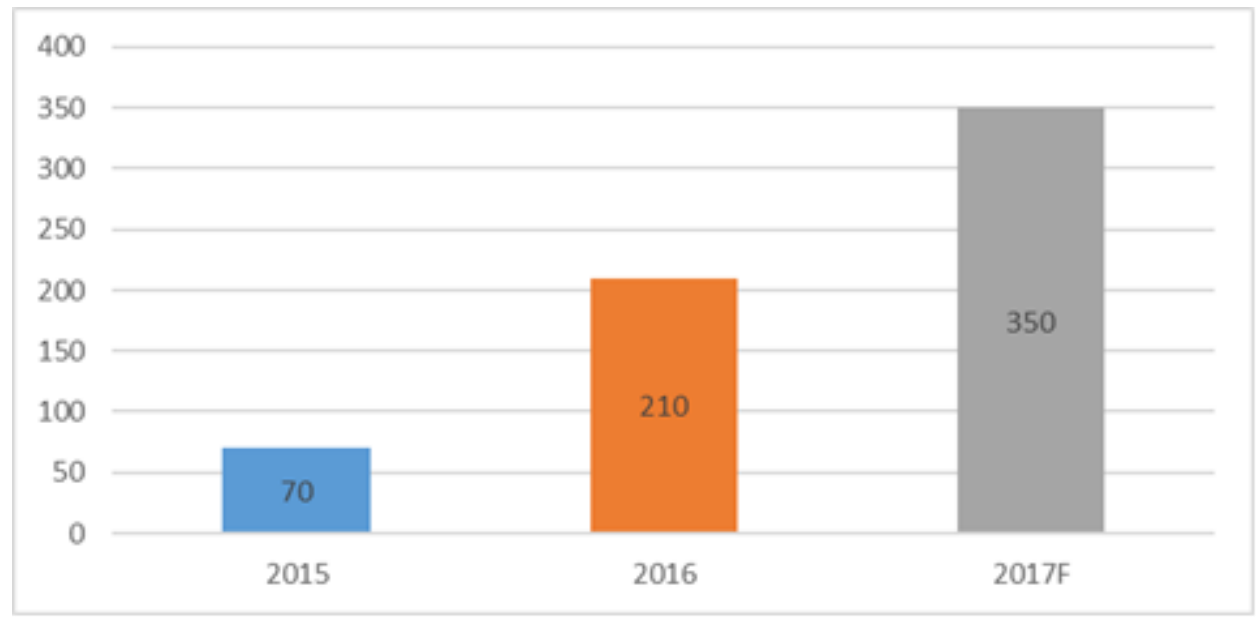

Figure 1. 2015-2017 Internet platform consumer credit balance (Billion RMB)

\subsection{The Online Credit Industry Chain}

For the B2C model, finance institutions provide funds to consumer platforms, so consumers could apply for a loan or payments by installments when making purchases as shown in Figure 2. The whole process is based on various scenes of consumption.

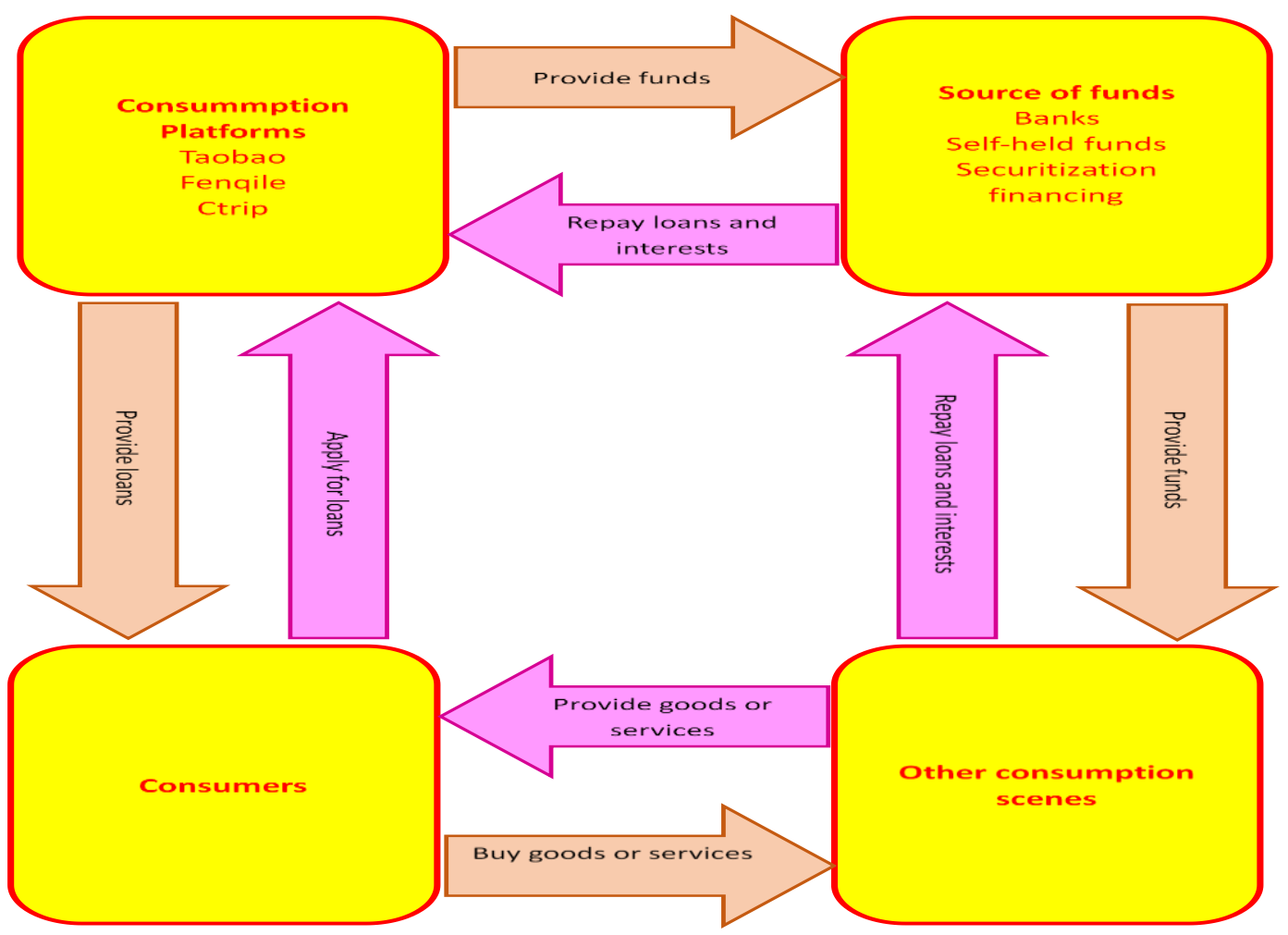

Figure 2. The B2C online credit industry chain 
For the P2P model, lenders and borrowers complete the transaction through an online lending platform that requires a commission from the borrowers as exhibited in Figure 3.

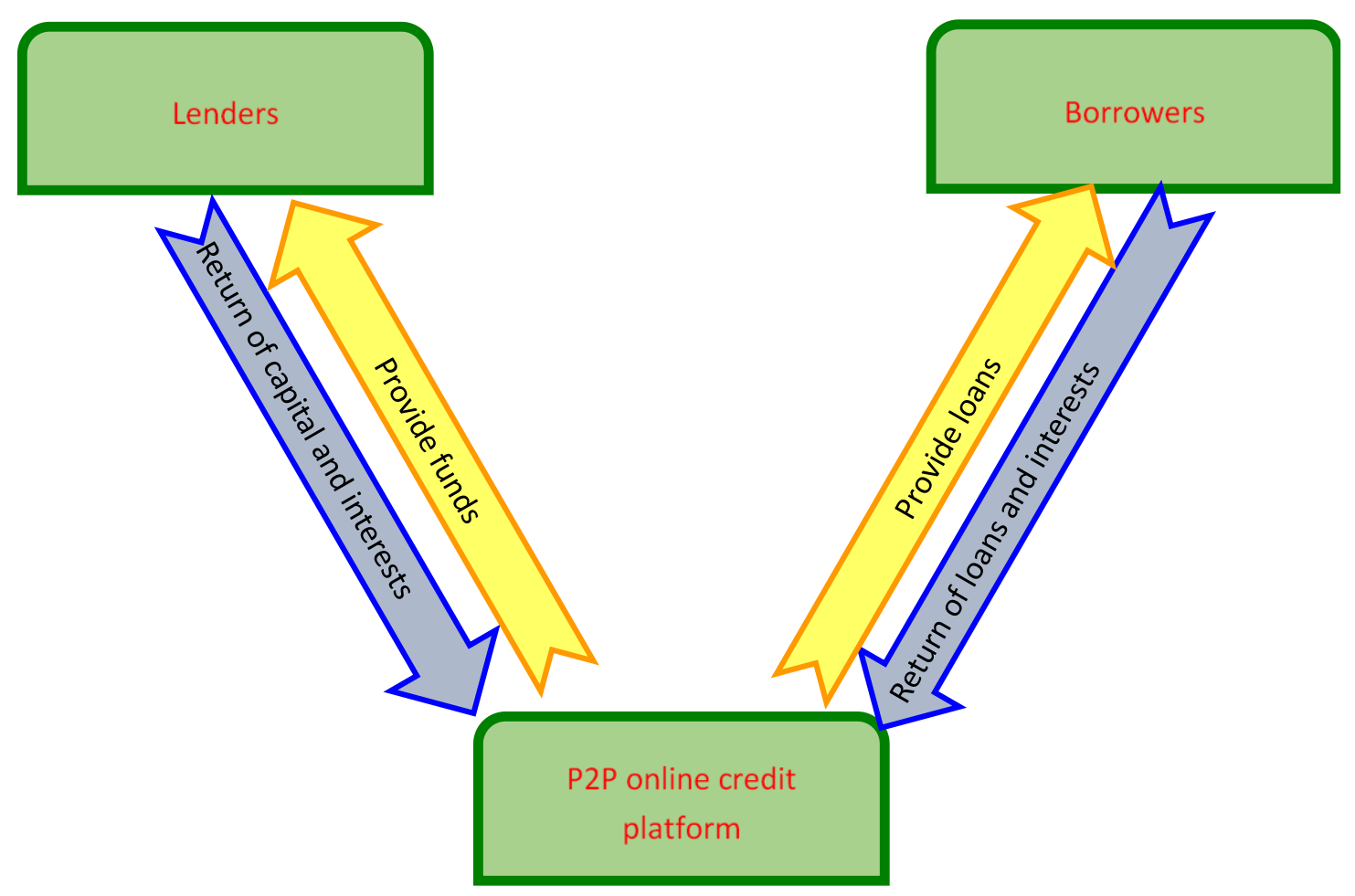

Figure 3. The $\mathrm{P} 2 \mathrm{P}$ online credit industry chain

\subsection{The comparison between traditional bank credit and online credit}

Online credit disrupts traditional bank credit, but the former will not have too much impact on the latter because they are very different. Targeted customers for bank credit are qualified bank customers, while online credit is aimed at lowand middle-income groups such as students and young people. For these services, they are often carried out by credit card, real estate mortgage or other properties. This is a larger loan amount, so all of the customer's credit information will be approved by the bank (Lin, 2009; Lin, Prabhala, \& Viswanathan, 2013). Online credit is easier. Since its loan amount is small, so all clients need to provide some personal information and no mortgage is required. Loans can be issued within minutes or hours of information approved (Hsueh \& Kuo, 2017).

Therefore, the competition between the two is not fierce, online lending concerns customer groups that banks did not cover in the past, and some credit card users. Online credit is still in the early stages of development. The B2C model operates primarily on shopping sites and will gradually expand into the offline retail sectors. In addition, the P2P model is less popular in China (Lin, 2009). Traditional credit will not be greatly affected because the credit market is expanding; certainly, there will be more and more competitors, but they are targeting different customer groups and different product positions, so the two sides will not be able to compete fiercely.

\section{The Comparison between Ant Check Later and Zopa}

There are many online lending companies around the world including Prosper in USA, Maneo in Japan, Silver Bullion in Singapore, Ppdai.com, My089.net, CreditEasy.com in China, GoPeer in Canada, Younited-Credit.com in France, but each has its own unique characteristics. In this section, we will perform a SWOT analysis of a Chinese company (Ant Check Later) and a UK company (Zopa) to study their business model differences.

\subsection{Presentation of Ant Check Later}

Ant Check Later (hereinafter referred to as ACL) is a service provided by Alipay, like the latter, it is also owned by Alibaba (Zhao, 2017). ACL cooperates with Taobao, Amazon, overseas shopping sites, etc. After opening this service, the user will receive an amount ranging from 500 to 50,000 yuan, which depends on the individual credit (Qian, 2015; Yang, 2015). When shopping at the cooperated sites, you can choose to pay by Alipay and then "pay by ACL" at the 
Alipay checkout. Users have to repay the money in the next month or months, of course the former will not exchange interest, while the latter will.

\subsection{Presentation of Zopa}

Zopa is a British company founded in 2005, describes a possible agreement area for sale and negotiations. Since 2005, Zopa has approved 3.20 billion loans (Gassmann, Frankenberger, \& Csik, 2014; Briceno Ortega \& Bell, 2008). The interest rate ranges from $2.9 \%$ to $34.9 \%$, which is often lower than that of banks. For example, a person wishing to borrow money at a certain rate of interest over a certain period and a person wishing to lend money at a certain rate. If both parties agree on a rate and a period, then a ZOPA can be established (McKnight \& Fish, 2016; Zopa.com, 2014).

\subsection{SWOT Analysis of Ant Check Later}

\subsubsection{Strengths}

\subsubsection{Mature cooperation platforms}

Benefiting from Alipay, ACL has a stable source of funding to provide loans to its customers. Many small and medium-sized credit platforms are constrained by the lack of funds to grow. In addition, ACL also conducted cooperation with large shopping sites, especially Taobao (Li, 2014; Lu, 2015), which has gained a large number of users.

\subsubsection{Low credit requirements}

The requirements for opening ACL are low: the user must be at least 18 years old and have an Alipay account with a real name registration. Compared to the complicated procedures for opening credit cards, it meets the needs of a large number of students who do not yet have a job (Carmen, Barney, Xiao, Tan, \& Yuan, 2017). According to recent statistical data, among nearly 170 million Chinese youth who are between 17 and 27 years old, there are over 45 million people who are using ACL. That is, 1 in 4 people in the group uses this micro-credit loan, the rate reaches $25 \%$. The increase in users makes ACL more and more popular.

\subsubsection{Weaknesses}

\subsubsection{Encourage young people to consume irrationally}

Since many young people do not yet have a job or with low income, ACL would lead them to excessive consumption; in fact, they do not have enough income to repay their debt, which risks locking them into a vicious cycle.

\subsubsection{Imperfect supervisory system}

Some people use ACL to cash on Taobao, which reflects the loopholes in the supervision and administration of the online credit industry (Chen, 2019). On the one hand, there is a lack of supervision at the legal level, which would lead to a lack of legal knowledge relevant to companies and users (Chen, 2018; Jiu, 2018). On the other hand, the supervision of online credit firms is too limited to control the risks. These loopholes would limit the development of online credit and the credit economy.

\subsubsection{Opportunities}

\subsubsection{Promote economic development}

Advanced consumption has made it possible to better free the consumption capacity of all classes, stimulating domestic demand (Yang, 2018), and plays a significant role in promoting economic development, in particular the rise of the market economy.

\subsubsection{Develop the credit economy}

After the users borrow money, they should make the repayment on time so as not to affect the further use of the financial technology (fintech)service (Kshetri, 2020). This process instills a concept of "credit" to the user. Since credit plays an important role for businesses and individuals to find their way into society and promote the development of the credit economy.

\subsubsection{Threats}

\subsubsection{Competition from traditional banks}


ACL relies heavily on the banking system and relies on the banks to perform the clearing. Once the banks ally, ACL will face serious threats. On the other hand, banks are also expanding to the Internet, as they have a mature financial system, they will threaten ACL's future development (Oustani, 2020).

\subsubsection{Competition from other internet-based companies}

Today, more and more Internet companies are launching credit services, this has led to fierce competition, like Jingdong Finance and WeChat-based lending services (CB Insights, 2018). In particular, WeChat, because it has a huge amount of money from millions of users, once WeChat and consumption sites come together, it is going to pose a huge threat to ACL (Asean Today 2017).

\subsection{SWOT analysis of Zopa}

\subsubsection{Strengths}

\subsubsection{Perfect risk control}

Zopa can directly use the national financial credit system and at the same time has the traditional finance identity and authority (Briceno Ortega, \& Bell, 2008). In terms of risk control, since Zopa has a high degree of access to credit information, it can be directly linked to the credit system and can instantly get customer credit records, such as car loans, mortgages, credit cards and so on.

\subsubsection{Freer Loan Destinations}

ZOPA's interest rate is often lower than that of banks (Altfi, 2016). Even though the credit information of different individuals will lead to the different interest rate.

Zopa's loan can be directly withdrawn, used to flip credit cards, buy a house, buy a car and so on.

Zopa offers loans ranging from $£ 1,000$ to $£ 25,000$ for a period of 1 to 5 years. The loan amount is high and long.

\subsubsection{Weaknesses}

\subsubsection{Long-term loan}

From start to finish, it shouldn't take more than 5 business days for the customer to receive the money (Gonzalez \& McAleer, 2011). But one can choose the 'Fast Track' option for $£ 10$.

Here is the breakdown:

Checking of personalized loan rates (3 minutes) and application (up to 30 minutes);

If Zopa cannot immediately approve the loan, the underwriting team will review the request (up to 2 business days); Once approved, Zopa will send the money to the chosen bank account. It takes up to 3 working days (or 1 working day if 'Fast Track' is chosen).

\subsubsection{Supervised by the credit system}

Since Zopa is managed by the credit system, all users who violate the contract during the term of the loan will be registered in the national credit information system (Huang, 2018). If the users do not pay the money back on time, it will make a negative trace which will affect the personal credit information, so this service will be more limited and stricter.

\subsubsection{Opportunities}

\subsubsection{Regional opening of the internet}

Zopa's business model is online: it breaks restrictions on traditional financial services, removes geographic restrictions and exhibits geographic openness (Milne \& Parboteeah, 2016). Zopa can take advantage of this geographic openness to extend the reach of its business activities.

\subsubsection{Improving information processing capacities}

With the development of information and communication technologies and cloud computing, relevant lender information can be obtained from the internet at low cost, thus laying the foundation for risk management.

\subsubsection{Threats}

\subsubsection{Hacking}


Online loan transactions must rely on the Internet. In the open internet environment, if there are any loopholes in the site, hackers will cripple the system (Milne \& Parboteeah, 2016), so that all investors opt out, leading to bankruptcy of the company.

\subsubsection{Competition from other enterprises credit online}

ZOPA's operation is very transparent, so its business model can easily be imitated. As we now discuss, in the UK there are other major online lending platforms such as RateSetter and Funding Circle (Milne \& Parboteeah, 2016). In a way, they're even more advanced than ZOPA, like the low bad debt ratio. Therefore, interest rate spreads, loan time and commission lead to a very fierce competition.

In general, although ACL is growing rapidly, but there is still a lot to learn from Zopa or other advanced companies. Especially when it comes to client approval and risk control, Zopa is more mature than most Chinese fintech companies as demonstrated in Table 1.

\begin{tabular}{|l|l|l|}
\hline & Ant Check Later & Zopa \\
\hline $\begin{array}{l}\text { Strong } \\
\text { points }\end{array}$ & $\begin{array}{l}\text { 1. A low opening required } \\
\text { 2. A cooperation with shopping sites } \\
\text { 3. A quick loan (in a few seconds) }\end{array}$ & $\begin{array}{l}\text { 1. Strict customer approval } \\
\text { 2. A large amount and a long-term loan } \\
\text { (1, 000 to } £ 25,000 \text { for a period of } 1 \text { to } 5 \\
\text { years })\end{array}$ \\
\hline $\begin{array}{l}\text { Weak } \\
\text { points }\end{array}$ & $\begin{array}{l}\text { 1. A small amount loan (500 to } 50,000 \text { yuan) } \\
\text { 2. No withdrawal of money }\end{array}$ & $\begin{array}{l}\text { 1. A slow loan (from } 3 \text { to } 5 \text { days) } \\
\text { 2. An unstable source of funds }\end{array}$ \\
& \multicolumn{2}{l}{ 3. A business model easy to copy } \\
\hline
\end{tabular}

Table 1. The comparison between Ant Check Later and Zopa

\section{Trends in Online Credit Development}

With the development of China's economy, people are facing an upgrade in consumption. How to resolve the contradiction between people's demand for material and lack of funds is an important question at the present time.

\subsection{Great market potential}

At the end of 2017, the Chinese consumer credit market reached 9.80 billion yuan, or $12.32 \%$ of GDP, against $20.26 \%$ in the United States, and the Chinese market will benefit from a very large development margin.

\subsection{Diversification of consumption scenes}

"E-commerce + finance" is an innovative business model for Internet consumer platforms (Guo \& Hu, 2014). As a cooperation between credit cards and entity stores, the two sides aim to launch promotional activities (Luo 2020), for example, bank \& Starbucks. Likewise, cooperation between financial institutions and consumption sites provides customers with a specific consumption environment (Guo, Lin, \& Li, 2020), which has effectively stimulated consumers' desire for consumption and loans. With the development of the internet, the consumption scenes on the internet have become more and more diverse, such as tourism, automobile, medical industry, etc., so does the online credit scene.

\subsubsection{Tourism}

In the past, people used to travel paying deposits, but now the innovative "tourism + online credit" model would encourage more people to travel, which would also promote the development of tourism (Feng, 2020; Chew, 2020; Chew, Shen, \& Ansell, 2020). The most beneficial group will be young people who have more time, but not enough funds. For example, Ctrip, Tuniu have cooperated with financial institutions to launch credit products that allow customers to "travel first, pay later" while Alibaba subsidiary Fliggy is cooperating with ACL to make customers pay by ACL. With the help of internet financing, the online travel industry has more possibilities.

\subsubsection{Automobile industry}

The "online credit + gas station" model allows customers to "get gas first, pay later"(Feng, Skouri, Wang, \& Teng, 2020). When the user refills the car at the gas station, s/he does not need to get out of the car to hand the credit card, but 
can make the payment with his/her mobile, and s/he will be able to benefit from additional discounts by this mode of payment. Based on this service, the platform could introduce more loan services, such as auto loans, auto insurance loans, etc., making the online credit scene more diverse (Chen, Gu, Li, Wang, Ying, Zhang, \& Zhao, 2018).

\subsubsection{Medical industry}

In China, medical costs are one of the highest expenses for the population. The "online credit + hospital" model will ease the pressure to pay medical costs. The user could "take treatments first, pay later". Besides, solving urgent problems, this service allows users to get better health service in advance to prevent disease and extend life.

\subsection{Better supervision}

Regulators should strengthen the supervision of the consumer credit industry in terms of authorized operations, interest rates, collection and borrowing, thereby promoting more standardized development of the industry and the emergence of consumer credit platforms.

\subsubsection{Licensed Company}

In the future, regulatory departments could strengthen regulatory oversight of online lending platforms, including requiring them to have an operating license.

\subsubsection{Strict regulation of interest rate}

Given the high interest rates on some platforms, regulatory departments will formulate more stringent regulations to restrict interest rate.

\subsubsection{Other more specific regulations}

Regulatory departments should also take necessary measures on the amount, destination of borrowing and recovery of loans in order to establish a healthy environment for online credit (Milne \& Parboteeah, 2016).

It is clear that credit can help the rational use of social resources and release the vitality of funds. In recent years, online credit has maintained a high growth rate and has gradually penetrated some areas of life. Being still at initial development stage, online credit still has a very large potential to boost China's economic growth. At the same time, the relevant departments should also strengthen the supervision of the credit market and dedicate their efforts towards creating a healthy environment for it.

\section{Conclusion}

In summary, there is still room for the development of online credit market. From the policy point of view, the Chinese government attaches great importance to the online credit market. Although its market entry requirements for enterprises are not too strict, but the government is gradually bringing necessary changes to allow advanced enterprises in the sector to make it better. From an economic standpoint, online credit will continue to stimulate domestic demand and promote economic growth and GDP growth (Manyika, Lund, Singer, White, \& Berry, 2016). In terms of society, peoples' concepts of consumption have changed. People's acceptance of credit is getting higher and higher because online credit can help Chinese people mainly younger generation improve their consumption levels (Yu, 2017). Technically speaking, with the development of the Internet, big data analytics can help businesses gain more accurate information about customers, better observe the economic capacity of the customer, and thus control the amount of loans. Of course, although the initial development of the online credit market has many imperfections, but it also requires more supervision from the government (Yue, 2017) and requires more innovation from the companies.

\section{Acknowledgements}

This research received no specific grant from any funding agency, commercial or not-for-profit sectors. We thank Dr. Suryappa J. PAWAR, Professor of Motilal Nehru National Institute of Technology, Allahābād (MNNIT) in India, the editor, and the anonymous reviewers of the International Journal of Business and Social Science for helpful comments on earlier versions of this article.

\section{References}

Ant Financial's “TechFin” vs JD Finance's "FinTech” (24 August 2017). Available: :https://www.aseantoday.com/2017/08/ant-financials-techfin-vs-jd-finances-fintech/

Bachmann, A., Becker, A., Buerckner, D., Hilker, M. Kock, M., Lehmann, M., \& Tiburtius, P. (2011). Online peer-topeer lending - a literature review. Journal of Internet Banking and Commerce, 16 (2), 1-18. Available: http://www.arraydev.com/commerce/jibc/. 
Carmen, L., Barney, T., Xiao, X., Tan, F. T. Chian, \& Yuan S., (April 2017). "Nurturing a FinTech ecosystem: The case of a youth microloan startup in China," International Journal of Information Management, Vol. 37, pp. 92-97. http://dx.doi.org/10.1016/j.ijinfomgt.2016.11.006

Chen D., \& Han C. (August 2012). A Comparative Study of online P2P Lending in the USA and China, Journal of Internet Banking and Commerce, vol. 17, no.2. Available: http://www.arraydev.com/commerce/jibc/

Chen S. (2018). Research on the Protection of Consumers in Peer to Peer Lending. The Second Issue of Legal System and Society, (4).

Chen, X. (2019). Legal Risk and Regulation of Peer to Peer Lending Industry in China, Advances in Economics, Business and Management Research, volume 94, 4th International Conference on Economy, Judicature, Administration and Humanitarian Projects (JAHP 2019). http://creativecommons.org/licenses/by-nc/4.0/).

Chen, Y., Gu Y., Li C., Wang Y., Ying Y., Zhang S., \& Zhao Y. (2018). China Consumer Finance Market Insights, Working Group of CFA China Shanghai CrowdResearch Project.

https://www.cfasociety.org/china/Documents/China\%20Consumer\%20Finance\%20Market\%20Insights_CFA $\%$ 20CrowdResearch_EN_final.pdf

Chew, B.C., Shen, X. \& Ansell, J. (2020). "Alipay entered Malaysia: a closer look at the new market entry strategy driven by Chinese tourists", Qualitative Research in Financial Markets, Vol. 12 No. 4, pp. 561-577. https://doi.org/10.1108/QRFM-06-2019-0069

Collier, B., \& Hampshire, R. (February 2010). Sending mixed signals: Multilevel reputation effects in peer-to-peer lending markets, Proceedings of the CSCW, Savannah, Georgia, USA, pp. 197-206. https://doi.org/10.1145/1718918.1718955

Croissance inédite du crédit à la consommation en ligne en Chine (2015). Available at : https://www.meilleurtaux.com/credit-consommation/actualites/2015-janvier/4394-croissance-inedite-credit-ala-consommation-en-ligne-en-chine.html

En Chine, le piège de l'argent facile des plateformes de prêts en ligne entre particuliers (18.12.2019). https://www.frenchweb.fr/en-chine-le-piege-de-largent-facile-des-plateformes-de-prets-en-ligne-entreparticuliers/387472\#gsc.tab $=0$

Feng, L., Skouri, K., Wang, W., \& Teng J. (2020). Optimal selling price, replenishment cycle and payment time among advance, cash, and credit payments from the seller's perspective. Annals of Operations Research. https://doi.org/10.1007/s10479-020-03761-y.

Feng, L. (2020). Alipay and WeChat Pay Comparative Study in Bangkok. MA Thesis, Siam University, Thailand.

Gassmann, O., Frankenberger, K., \& Csik, M. (2014). The Business Model Navigator: 55 Models That Will Revolutionise Your Business, Pearson Education: Harlow, UK. https://doi.org/10.1111/radm.12145.

Gonzalez, L., \& McAleer, K. (December 2011). Online Social Lending: A Peak at U.S. Prosper \& U.K. Zopa, Journal of Accounting, Finance and Economics, Vol. 1. No. 2. Pp. 26-41.

Guo, J., Lin J., \& Li L. (2020): Building users' intention to participate in a sharing economy with institutional and calculative mechanisms: an empirical investigation of $\mathrm{DiDi}$ in China, Information Technology for Development. https://doi.10.1080/02681102.2020.1807894.

Guo, Y., \& Hu Jun (July 2014). Research on Business Model Innovation of E-Commerce Era, International Journal of Business and Social Science, Vol. 5, No. 8.

Huang, R.H. (2018). Online P2P Lending and Regulatory Responses in China: Opportunities and Challenges. European Business Organisation Law Review, 19, 63-92. https://doi.org/10.1007/s40804-018-0100-z

Huang, (Robin) Hui (2018). Online P2P Lending and Regulatory Responses in China: Opportunities and Challenges (December 24, 2016). European Business Organization Law Review, (2018) Vol 19(1), 63-92. Available: SSRN: https://ssrn.com/abstract=2991993

Hsueh, S.-C., \& Kuo C.-H. (August 2017). Effective Matching for P2P Lending by Mining Strong Association Rules. ICIBE 2017: Proceedings of the 3rd International Conference on Industrial and Business Engineering, pp. 3033. https://doi.org/10.1145/3133811.3133823

Jiu, B. (2018). Analysis of Risk and Prevention of Peer to Peer Lending Platform. Legality Vision. (2).

Kshetri, N. (2020). China's Emergence as the Global Fintech Capital and Implications for Southeast Asia. Asia Policy 27(1), 61-81. https://doi.10.1353/asp.2020.0004.

Lin, M.F. (2009). Peer-to-peer lending: An empirical study, Proceedings of the AMCIS 2009 Doctoral Consortium, San Francisco, California, pp. 1-7.

Lin, M., Prabhala, N. R., \& Viswanathan, S. (2013). Judging borrowers by the company they keep: Friendship networks and information asymmetry in online peer-to-peer lending. Management Science, 59(1), 17-35. https://doi.org/10.1287/mnsc. 1120.1560

Li, Q. (August 26, 2014). A New Platform for Financial Management—Zhaocaibao. Zhe Jiang Daily, 11. 
Lu, Y. F. (2015) Small Sesame and Big Ambition. New Economy, 9, 54-55.

Manyika, J., Lund S., Singer, M., White, O., \& Berry, C. (September 2016). Digital Finance for All: Powering Growth in Emerging Economics, McKinseyGlobal Institute. file:///C:/Users/DIDIBA 1/AppData/Local/Temp/MGIDigital-Finance-For-All-Executive-summary-September-2016.pdf.

McKnight, J., \& Fish, A. R. (2016). Zopa's lambs:video ads, internet banks, and the financialization of affect. Ephemera: Theory and Politics in Organization, 16 (4). pp. 33-49. ISSN 1473-2866. Available: https://eprints.lancs.ac.uk/id/eprint/79424

Milne, A., \& Parboteeah, P. (May 2016). The Business Models and Economics of Peer-to-Peer Lending, Research Report of European Credit Research Institute, No.17.

Briceno Ortega, A.C., \& Bell, F. (2008). Online Social Lending: Borrower-generated Content, Proceedings of the Fourteenth Americas Conference on Information Systems (AMCIS 2008), Toronto, ON, Canada August 14th17th. Available: https://aisel.aisnet.org/amcis2008/380.

Oustani, N.M. (2020) Traditional Banks and Fintech: Survival, Future and Threats. In: Baghdadi Y., Harfouche A., Musso M. (eds) ICT for an Inclusive World. Lecture Notes in Information Systems and Organisation, Vol 35. Springer, Cham. https://doi.org/10.1007/978-3-030-34269-2_24.

Patsuris, P. (1998). Cut out the middleman, Forbes.

Qian, H.L. (2015) Ant Check Later on the Line. Computer and Network, 1, 10.

Schiller, D. (1999). Digital Capitalism: Networking the Global Market System, (Cambridge, Mass.: MIT Press) 294 pp. ISBN 026219417 1. Convergence, 6(2) : 126-128. https://doi.org/10.1177/135485650000600211

Torre, D., \& Xu, Q. (2019). La Chine aux avant-postes de la digitalisation des paiements, Revue d'économie financière, Vol.3, no.135, pp. 99 à 114. https://doi.org/10.3917/ecofi.135.0099.

Yang, T. (2015) Innovation and Development of Consumer Finance in Internet Era. Zhejiang Economy, 13, 16-17.

Yang, J. (2018). The Status and Prospects of International Finance Credit Services at Bangkok — A Case Study Based on Ant Check Later, An IMBA Thesis at Siam University, Thailand.

The numbers behind Zopa's interest rate cuts (1 November 2016). Available: https://www.altfi.com/article/2362_the_numbers_behind_zopas_interest_rate_cuts.

What The Largest Global Fintech Can Teach Us About What's Next In Financial Services (October 4, 2018). Available at : https://www.cbinsights.com/research/ant-financial-alipay-fintech/

Yue, H. (2017). National Report on E-commerce Development in China, Inclusive and Sustainable Industrial Development Working Paper Series WP 17. United Nations Industrial Development Organization.

Yu, H. (2017 - Au-delà du e-commerce ? Perspectives chinoises [En ligne], 2017/4 | 2017, mis en ligne le 15 décembre 2017, consulté le 01 mai 2019. URL: http://journals.openedition.org/perspectiveschinoises/7884.

Zhao, Y.N. (2017). Research on the Consumer Finance System of Ant Financial Service Group. American Journal of Industrial and Business Management, 7, 559-565. https://doi.org/10.4236/ajibm.2017.75041.

Zopa Limited (2013). “Zopa Lambs.” Available at: [http://youtu.be/FhvI8x1kH38]___ (2014). [http://zopa.com]. 